\title{
Penggunaan Kobesi dalam Matematika Gasing untuk Meningkatkan Pemahaman Materi Perkalian Siswa SD
}

\author{
Hendy Halyadi ${ }^{1}$, Dede Agustianie ${ }^{2}$, Tri Handayani ${ }^{3}$, Hening Windria ${ }^{4}$ \\ Sekolah Tinggi Keguruan dan Ilmu Pendidikan Surya \\ e-mail: hendy.halyadi@students.stkipsurya.ac.id
}

\begin{abstract}
ABSTRAK. Penelitian ini bertujuan untuk mengetahui tentang peningkatan kemampuan pemahaman matematis siswa menggunakan KOBESI dalam Matematika GASING. Penelitian ini menggunakan pretest-posttest control group desain. Sampel penelitian melibatkan 24 siswa Sekolah Dasar di Desa Curug Sangereng yang terdiri dari 2 kelas yaitu kelas kontrol dan kelas eksperimen. Pengumpul data berupa soal tes kemampuan pemahaman matematis, dan pedoman wawancara. Dari pembahasan hasil penelitian, diketahui bahwa terjadi peningkatan pemahaman yang signifikan terhadap materi perkalian pada kelas yang mendapatkan pembelajaran matematika menggunakan KOBESI dalam Matematika GASING. Selain itu sebagian besar siswa menunjukkan sikap positif terhadap penggunaan KOBESI di dalam pembelajaran matematika, maka pembelajaran matematika dengan penggunaan KOBESI dalam Matematika GASING sangat potensial diterapkan di lapangan dalam upaya meningkatkan kualitas pendidikan.
\end{abstract}

Keywords : kemampuan pemahaman matematis, kobesi, matematika

\section{PENDAHULUAN}

Perkalian adalah salah satu dari empat operasi aritmatika dasar dan didefinisikan sebagai penjumlahan berulang (West dan Bellevue, 2011). Sebagai contoh 2x3 diartikan sebagai 3+3. Perkalian merupakan salah satu topik matematika yang sangat penting dalam pembelajaran karena banyak penerapannya dalam kehidupan sehari-hari. Tidak banyak siswa yang mampu memahami tentang apa itu operasi perkalian.

Hal ini diperkuat dengan masalah yang sering muncul dilapangan, dimana sulitnya dalam membelajarkan siswa agar dapat terampil dalam perkalian dasar. Siswa mengalami kesulitan dalam menerima pelajaran perkalian, Sulit memahami, sulit diajak untuk terampil perkalian dasar, dan juga sulit dalam menimbulkan minat belajar siswa terhadap materi perkalian. Siswa hanya menghafal perkalian begitu saja tanpa paham konsep dari perkalian itu sendiri. Sedangkan disisi lain perkalian adalah topik yang harus dikuasai oleh siswa sejak dini karena topik ini akan selalu terkait dengan pelajaran matematika di kelas berikutnya atau di jenjang yang lebih tinggi.

Peneliti juga menemukan suatu kondisi di salah satu Sekolah Dasar (SD) Tangerang di daerah Curug Sangereng dimana para siswa mengalami kesulitan untuk memahami materi perkalian. Hal ni diperkuat dengan 8 angket yang diterima dari 9 angket yang diberikan atau disebarkan kepada 9 guru di SD Curug Sangereng yang menunjukkan bahwa kurang menilai siswa kurang memahami materi perkalian. Dari hal ini dapat disimpulkan bahwa masih kurangnya pemahaman siswa terhadap materi perkalian dan respon yang sangat minim dari siswa pada penyampaian materi perkalian pada saat proses kegiatan belajar mengajar di dalam kelas.

Pemahaman dan minat siswa pada materi perkalian harus sangat tinggi. Hal ini dikarenakan perkalian merupakan suatu materi yang nantinya akan diagunakan siswa dalam kehidupan sehari- 
hari. Hal ini diperkuat dengan pendapat Septi (dalam Nurmasari, 2010), yang menyatakan beberapa manfaat berhitung, diantaranya;

1)Agar anak kita dapat lebih memahami alam semesta dan hukum-hukum yang berlaku di dalamnya, 2) agar anak kita dapat melakukan perencanaan dan evaluasi dengan baik saat dewasa nanti, 3) agar anak-anak kita dapat membuat rancangan dan konstruksi dengan benar, 4) yang juga tidak kalah penting adalah agar anak-anak kita dapat berlaku adil, 5) kemudian agar mereka tidak mudah tertipu, 7) dan tentu masih banyak lagi nilai pentingnya bagi kehidupan anak kita.

Dengan hal diatas jelas bahwa minat dan pemahaman siswa terhadap materi perkalian harus dapat ditingkatkan.

Menurut Mediawati (2011) media pembelajaran adalah media yang membawa pesanpesan atau informasi yang bertujun intrruksional atau mengandung maksud-maksud pengajaran. Media pembelajaran bisa dipahami sebagai media yang digunakan dalam proses belajar mengajar untuk mencapai tujuan pembelajaran. Dari hal diatas maka diharapkan penggunaan media pembelajaran KOBESI (KOtak BEriSI) dalam Matematika GASING (Gampang, Asik menyenaNGkan) dapat digunakan di dalam proses pembelajaran dan meningkatkan kemampuan pemahaman matematis siswa.

Media pembelajaran KOBESI merupakan media yang dapat meningatkan kemampuan pemahaman siswa terhadap materi perkalian dan dapat meningkatkan respon siswa. Hal ini dikarenakan media pembelajaran ini dapat membantu siswa dalam memahami materi perkalian yang sulit dipahami dan abstrak bagi siswa kelas III SD Curug Sangereng. Hal ini dapat dipaparkan atas dasar bentuk dari KOBESI itu sendiri yang merupakan kotak yang berisikan beberapa bola yang dapat disesuaikan tergantung soal.

Materi perkalian merupakan salah satu bentuk operasi dalam aritmatika yang sangat penting untuk dipelajari. Perkalian adalah salah satu dari empat operasi aritmetika dasar dan didefinisikan sebagai penjumlahan berulang (West dan Bellevue, 2011). Sedangkan menurut Septi (Nurmasari, 2010) manfaat berhitung tidak lain untuk membentuk siswa yang siap untuk terjun ke dunia kerja, benar dalam melakukan perhitungan, dan pada kelas selanjutnya dengan modal berhitung. Dengan dua poin ini terjawab bahwa pentingnya materi perkalian untuk dipelajari.

Kondisi dilapangan memperlihatkan tingkat pemahaman dan respon siswa pada materi perkalian di kelas III SD Curug Sangereng sangat rendah. Tidak hanya hasil dari data angket yang didapat pada penyebaran kepada 9 guru di sekolah tersebut, hal ini juga didapat dan diperkuat dari beberapa sudut pandang lainnya yang juga dikuatkan dengan data yang ada. Hal ini tidak lain seperti data yang didapat pada hasil uji empiris yang diberikan kepada siswa kelas V pada SD yang sama. Dengan kenyataan yang didapat dilapangan, maka peneliti tertarik untuk mengimplementasikan KOBESI dalam pembelajaran di kelas.

Berdasarkan permasalahan diatas, peneliti ingin mengimplementasikan KOBESI pada materi perkalian untuk meningkatkan pemahaman siswa terhadap materi perkalian dan untuk dapat menigkatkan respon siswa terhadap materi perkalian.

\section{TINJAUAN PUSTAKA}

\section{Kemampuan Pemahaman Matematis}

Pemahaman diartikan dari kata understanding yang diartikan sebagai penyerapan arti suatu materi yang dipelajari (Sumarmo dalam Novianda, 2015). Pemahaman berasal dari kata "faham" yang berarti tanggap, mengerti benar, pandangan, dan ajaran. Disini ada pengertian tentang pemahaman yaitu: kemampuan memahami arti suatu bahan pelajaran (Partanto: 1994), seperti menafsirkan, menjelaskan atau meringkas atau merangkum suatu pengertian kemampuan seperti ini lebih tinggi dari pada pengetahuan. 
Pemahaman juga merupakan tingkat berikutnya dari tujuan ranah kognitif berupa kemampuan memahami atau mengerti tentang isi pelajaran yang dipelajari tanpa perlu mempertimbangkan atau memperhubungkannya dengan isi pelajaran lainnya. Menurut Bani (2011) kemampuan pemahaman matematik adalah salah satu tujuan penting dalam pembelajaran, memberikan pengertian bahwa materi-materi yang diajarkan kepada siswa bukan hanya sebagai hafalan, namun lebih dari itu dengan pemahaman siswa dapat lebih mengerti akan konsep materi pelajaran itu sendiri.

Menurut NCTM (2000) kemampuan pemahaman siswa dapat dilihat dalam :

1. Mendefinisikan konsep secara verbal dan tulisan

2. Membuat contoh dan non contoh penyangkal

3. Mempresentasikan suatu konsep dengan model, diagram, dan simbol

4. Mengubah suatu bentuk representasi kebentuk yang lain

5. Mengenal berbagai makna dan interprestasi konsep

6. Mengidentifikasi sifat-sifat suatu konsep dan mengenal syarat-syarat yang menentukan konsep

7. Membandingkan dan membedakan konsep-konsep.

Merujuk pada taksonomi Bloom, Sumaryati (2013) mengidentifikasi kemampuan pemahaman matematis dalam tiga jenis perilaku kognitif yaitu mengubah dari satu bentuk matematis ke bentuk matematis lain, menginterpretasi suatu konsep, prinsip, dan ekspresi matematis, dan mengintrapolasi dan mengekstrapolasi suatu kecenderungan data.

Dari beberapa indikator diatas peneliti mengambil beberapa indikator kemampuan pemahaman matematis siswa yang akan digunakan dalam penelitian diantaranya yaitu :

1. Mempresentasikan suatu konsep dengan model, diagram, dan simbol

2. Mengubah suatu bentuk representasi kebentuk yang lain

3. Mengenal berbagai makna dan interprestasi konsep

4. Mengidentifikasi sifat-sifat suatu konsep dan mengenal syarat-syarat yang menentukan konsep

5. Membandingkan dan membedakan konsep-konsep.

\section{Matematika GASING}

Matematika GASING (GAmpang, aSyIk dan menyenaNGkan) merupakan suatu cara belajar matematika secara mudah, asyik dan menyenangkan, yang dikembangkan oleh Prof Yohanes Surya untuk meningkatkan pendidikan matematika di Indonesia. Mudah karena pembelajaran ini diawali dengan sesuatu yang konkrit, asyik karena adanya penggunaan games dalam pembelajaran, dan menyenangkan karena selama belajar siswa tidak dipaksa. Dalam pembelajaran dengan menggunakan matematika GASING ada tahap yang harus dikuasai siswa yang disebut dengan "Titik Kritis GASING". Apabila siswa menguasai titik kritis GASING maka siswa akan mudah dalam menjawab soal matematika yang diberikan (Siregar dkk, 2014).

Pembelajaran Matematika GASING pada materi perkalian dimulai dengan perkalian bilangan 1-10, sekaligus merupakan cara untuk menuju titik kritis GASING perkalian. Titik kritis perkalian sendiri adalah perkalian bilangan 100 kebawah. Untuk mencapai titik kritis GASING ini yang diperlukan adalah peserta didik harus mengerti konsep perkalian dengan baik, kemudian dilanjutkan dengan bagaimana menghitung perkalian bilangan 1,10,9,2, dan 5. Selanjutnya adalah perkalian untuk bilangan yang sama, perkalian bilangan 3 dan 4, dan yang terakhir adalah perkalian 8,7, dan 6 (Surya, 2013). 


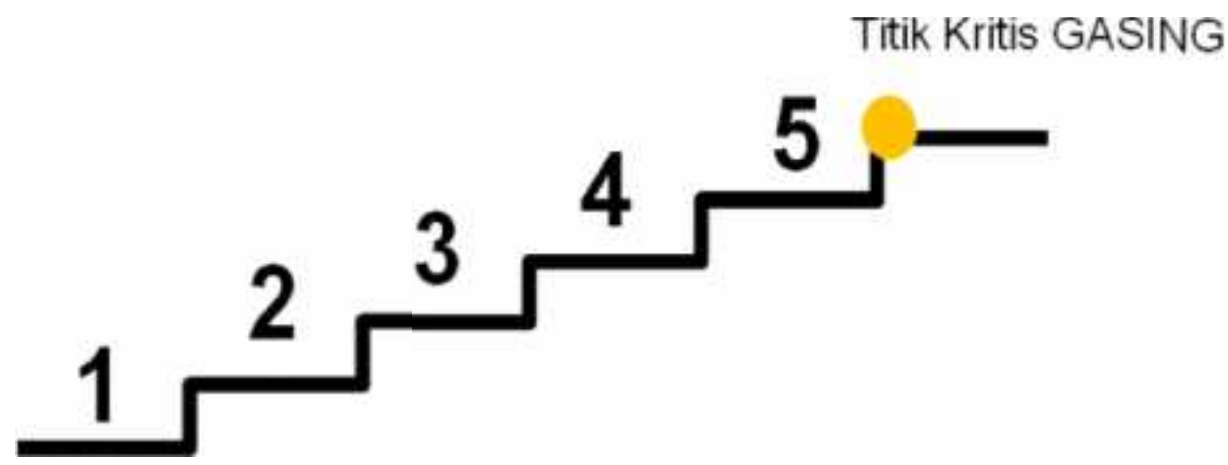

Gambar 1. Titik kritis GASING perkalian.

Keterangan :

1. Konsep perkalian

2. Perkalian 1, 10, 9, 2, dan 5

3. Perkalian bilangan yang sama

4. Perkalian 3, 4

5. Perkalian $8,7,6$

\section{Media Pembelajaran KOBESI}

Media adalah alat yang menyampaikan atau mengantarkan pesan-pesan pengajaran. Menurut Sadiman dkk. (dalam Sriyani, 2014) media pembelajaran adalah paduan antara bahan dan alat atau perpaduan antara software dan hardware. Media pembelajaran bisa dipahami sebagai media yang digunakan dalam proses belajar mengajar untuk mencapai tujuan pembelajaran.

Media pembelajaran KOBESI adalah suatu media pembelajaran yang dapat membantu peserta didik dalam memahami konsep dasar perkalian. Media pembelajaran tersebut juga merupakan media pembelajaran yang terdiri dari kotak-kotak persegi dan beberapa bola kecil. Kotak-kotak persegi pada media pembelajaran tersebut terbuat dari kertas mika yang biasanya digunakan untuk menjilid, sedangkan bolanya menggunakan bola pingpong. Berikut ini contoh penggunaan media pembelajaran KOBESI :

$3 \times 2$, artinya terdapat 2 kotak dimana masing-masing kotak berisi 3 bola. Yang terlihat seperti pada gambar dibawah ini .
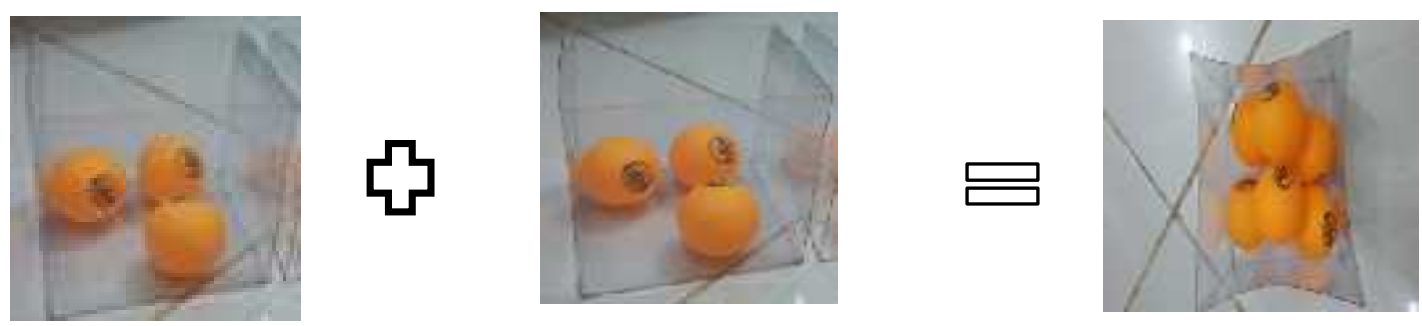

Gambar 2. Arti dari $2 \times 3$

\section{METODE PENELITIAN}

Metode yang digunakan dalam penelitian ini adalah penelitian eksperimen dengan desain penelitian yang digunakan yaitu true-experiment dengan jenis Pretest-Postest control group design. Pada penelitian ini akan dipilih dua kelas secara acak dimana masing-masing kelas akan mendapat treatment atau perlakuan yang berbeda. Adapun pelaksanaan penlitian ini dilaksanakan di SD Curug Sangereng dengan sampel penelitiannya adalah siswa kelas III SD, karena siswa kelas III 
hanya terdiri dari satu kelas maka kelas tersebut dibagi menjadi dua yaitu kelas kontrol dan kelas eksperimen dimana masing-masing kelas terdiri dari 12 siswa. Teknik pemilihan sampel dilakukan secara acak baik itu kelas kontrol maupun kelas eksperimen. Variabel bebas atau variabel independen dalam penelitian ini adalah penggunaan Media KOBESI dalam Matematika GASING, sedangkan variabel terikat atau variabel dependen adalah kemampuan pemahaman matematis siswa pada materi perkalian. Untuk mengukur kemampuan pemahaman matematis siswa yaitu dengan menggunakan instrumen.

Instrumen tes yang digunakan untuk mengukur kemampuan pemahaman matematis siswa adalah sebanyak 5 soal yang berupa soal uraian. Sebelum menyusun instrumen tes, terlebih dahulu peneliti membuat kartu soal berdasarkan indikator yang akan diujikan. Kartu soal yang dibuat yaitu sebanyak 10 soal yang kemudian divalidasi oleh pakar atau ahli untuk melihat kesesuain instrumen tersebut terhadap materi perkalian dan telah mewakili keseluruhan indikator pemahaman matematis siswa. Kemudian, instrumen tersebut diujikan pertama kali kepada siswa kelas V SD yang berjumlah 16 siswa. Setelah diujikan kepada siswa kelas V selanjutnya dilakukan uji validitas dan reliablitas menggunakan Microsoft excel. Sehingga dipilih 5 soal yang valid dan reliabilitas untuk digunakan sebagai soal pretest dan posttest untuk kelas kontrol dan kelas eksperimen.

Pada kelas kontrol dan kelas eksperimen diberikan perlakuan yang berbeda dimana untuk kelas kontrol diberikan perlakuan dengan model pembelajaran secara konvensional dengan metode ceramah dan perlakuan yang diberikan pada kelas eksperimen adalah pembelajaran dengan menggunakan media KOBESI dalam Matematika GASING. Sebelum diberikan perlakuan terhadap kedua kelas masing-masing kelas diberikan pretest terlebih dahulu untuk melihat kemampuan awal siswa.

Kemampuan pemahaman matematis siswa terhadap materi perkalian diukur dari bagaimana siswa dalam memahami materi sesudah dan sebelum diberikan perlakuan dikelas yang diukur dengan menggunakan instrumen penelitian yaitu berupa soal pretest dan posttest. Data berupa nilai peretest dan posttest dari masing-masing kelas inilah yang akan dianalisis dengan menggunakan uji normalitas, uji homogenitas, N-Gain serta dilakukan uji t, untuk melihat peningkatan pemahaman matematis siswa setelah diberikan perlakuan. Pengolahan data dilakukan dengan menggunakan bantuan program SPSS.

\section{HASIL DAN PEMBAHASAN}

\section{Peningkatan Kemampuan Pemahaman Matematis}

Variabel kemampuan pemahaman matematis diukur dengan menggunakan instrumen yang terdiri dari 5 soal. Dengan skor masing-masing soal adalah 10, untuk nilai yang diperoleh didapat dari jumlah skor lalu dibagi dengan 5. Berdasarkan hasil penelitian, didapatkan data berupa nilai pretest dan posttest siswa. Setelah semua data telah dikumpulkan, maka selanjutnya kita lakukan uji normalitas, homogenitas dan uji t apabila data normal dan homogen.

Untuk nilai pretest dilakukan uji normalitas dan homogenitas. Dari hasil pengolahan uji normalitas pada data nilai kelas kontrol dengan bantuan program SPSS didapat $p=.121>0.05$, dari hal itu dapat disimpulkan bahwa data nilai pretest untuk kelas kontrol berdistribusi normal. Sedangkan untuk nilai peretest kelas eksperimen didapatkan $p=.200>0.05$, maka dapat disimpulkan bahwa data nilai pretest kelas eksperimen berdistribusi normal. Setelah dilakukan uji normalitas pada data pretest kelas kontrol dan kelas eksperimen selanjutnya dilakukan uji homogenitas karena data nilai pretest kedua kelas berdistribusi normal. Dari hasil uji homogenitas data nilai pretest didapatkan $p=.113>0.05$, maka dapat disimpulkan bahwa datanya homogen. Karena data nilai pretest kedua kelas berdsitribusi normal dan homogen, maka selanjutkan dilakukan uji t.

Dari hasil uji $\mathrm{t}$ terhadap nilai pretest antara kedua kelas didapat kesimpulan bahwa tidak terdapat perbedaan kemampuan pemahaman matematis antara siswa kelas kontrol $(\mathrm{M}=3.7833$ 
$\mathrm{SD}=.62353)$ dan siswa kelas eksperimen $(\mathrm{M}=3.0833 \mathrm{SD}=1.18001)$, dimana dari hasi uji $\mathrm{t}$ didapatkan $t(22)=1.817 p=0.083<0.05$, dan $d=0.7417$. Tidak hanya secara statistika dilihat dari cohensnya atau dilapangan memang tidak terdapat perbedaan kemampuan pemahaman matematis siswa sebelum diberikan perlakuan. Oleh karena itu apabila pada data posttest terdapat peningkatan kemampuan pemahaman matematis terhadap materi perkalian maka hal itu disebabkan perlakuan yang telah diberikan pada kelas tersebut.

Untuk melihat apakah terdapat perbedaan pemahaman matematis siswa antara kelas kontrol dan kelas eksperimen maka dilakukan uji statistika terhadap nilai posttest yang didapatkan pada penelitian. Dari hasil uji normalitas pada data nilai posttest siswa kelas kontrol didapatkan $p=$ $0.200>0.05$, maka dapat disimpulkan bahwa data kelas kontrol berditribusi normal. Sedangkan pada kelas eksperimen $p=0.200>0.05$, sehingga dapat disimpulkan bahwa data kelas eksperimen berdistribusi normal. Kemudian dilakukan uji homogenitas karena data kedua kelas berdistribusi normal. Adapun hasil dari uji homogenitas didapatkan $p=0.499>0.05$, maka dapat disimpulkan bahwa data homogen. Karena data kedua kelas normal dan homogen maka selanjutnya dilakukan uji t.

Dari hasil Uji t terhadap nilai posttest pada kelas kontrol $(\mathrm{M}=5.2500, \mathrm{SD}=1.23913)$ dan kelas eksperiman $(\mathrm{M}=7.0333, \mathrm{SD}=1.17499)$ didapatkan $t(22)=-3.618 p=.002$ dan $\mathrm{d}=$ 1.47687, karena $p<0.05$ maka dapat disimpulkan bahwa terdapat perbedaan peningkatan kemampuan pemahaman matematis siswa antara kelas kontrol dan kelas eksperimen. Selain itu dilihat dari rata-rata nilai posttest diantara kedua kelas, dimana rata-rata posttest kelas eksperimen lebih tinggi dibandingkan dengan rata-rata kelas kontrol.

Perbedaan peningkatan kemampuan pemahaman matematis lebih tinggi kelas eksperimen dibandingkan dengan kelas kontrol. Perbedaan ini dapat dilihat dari rata-rata N-gain kedua kelas. Dimana rata-rata $\mathrm{N}$-gain kelas kontrol sebesar 0.2363 sedangkan pada kelas eksperimen rata-rata N-gainnya adalah 0.5661 .

Berdasarkan hasil perhitungan data nilai posstest yang telah didapat dan dipaparkan diatas, didapat bahwasanya proses pembelajaran dengan menggunaan KOBESI mengalami peningkatan dari segi pemahaman yang dilihat dari hasil belajar. Hal ini dikarenakan media pembelajaran KOBESI merupakan suatu media pembelajaran yang dapat membantu siswa dalam memahami konsep dasar perkalian. Tidak hanya itu, pembelajaran dengan menggunakan KOBESI dapat membuat siswa lebih mudah dalam memahami materi perkalian yang disampaikan di dalam kelas pada saat kegiatan belajar mengajar berlangsung, yang mana siswa dapat mengkonstruksi/ membangun konsep-konsep dan prinsip-prinsip materi yang sedang dipelajarinya. Hal ini sesuai dengan pernyataan Hudoyo (dalam Sukayati, 2003) bahwa belajar matematika merupakan proses membangun/mengkonstruksi konsep-konsep dan prinsip-prinsip, tidak sekedar penggrojokan yang terkesan pasif dan statis, namun belajar itu harus aktif dan dinamis.

\section{Melihat Respon Siswa}

Untuk mengetahui bagaimana respon atau tanggapan siswa terhadap model pembelajaran yang peneliti berikan, maka peneliti melakukan wawancara dengan beberapa siswa. Wawancara dilaksanakan pada Kamis 11 November 2015. Ada 4 siswa yang dipilih acak di kelas eksperimen untuk diwawancarai secara bergantian satu persatu tentang tanggapan-tanggapan mereka setelah mengikuti pembelajaran dengan menggunakan KOBESI dalam Matematika GASING. Siswasiswa tersebut adalah siswa-1, siswa-2, siswa-3 dan siswa-4.

Pedoman wawancara berupa pertanyaan-pertanyaan yang disusun untuk melakukan tanya jawab terhadap kegiatan pembelajaran dengan menggunakan KOBESI dalam Matematika GASING yang telah berlangsung. Pedoman wawancara yang digunakan dalam penelitian ini adalah pedoman wawancara untuk digunakan dalam mewawancarai siswa, yaitu digunakan untuk mengetahui sikap atau tanggapan siswa terhadap pembelajaran matematika dengan KOBESI dalam Matematika GASING untuk meningkatkan kemampuan pemahaman matematis yang 
masih kurang jelas ketika diamati secara langsung. Berikut adalah hasil wawancara peneliti dengan salah satu siswa tersebut:

Peneliti : "Pertama kakak mau nanya, adek lebih senang belajar menggunakan bola-bola dan kotak (KOBESI) atau cara belajar yang biasa?"

Siswa-1 : "Aku lebih senang kalau belajarnya pake bola-bola kak" (Dengan malu-malu menjawab dan tersenyum)

Peneliti : "Alasan adek memilih cara belajar dengan bola-bola lebih menyenangkan, kenapa?"

Siswa-1 : "Karena kalau pake bola-bola bisa sambil main kak, juga lebih mudah diingat cara menjawab soalnya, menyenangkan, dan mudah dimengerti juga kak." (Sambil memegang bola-bola yang saya simpan didekatnya)

Peneliti : "Ouh gitu, bagus dong dek. Jadi kamu lebih suka pake KOBESI ya dalam belajar perkalian? Dan juga kakak mau nanya ni dek, kamu lebih cepat ngerti belajar perkalian kalau pake KOBESI atau dijelasin biasa aja pake papan tulis?"

Siswa-1 : "Iya kka, lebih senang pake KOBESI. Kalau belajar perkalian aku lebih cepat ngerti kalau pake KOBESI kak dari belajar kalau pake papan tulis. Karena kalau pake papan tulis belajarnya ngantuk kak, susah ngertinya kak trus tegang juga."

Peneliti : "Ouh gitu, oke dek. Sudah ni, kakak sudah selesai nanyanya. Makasih ya sudah bantu kakak."

Siswa-1 : "Sama-sama kak"

Dari hasil wawancara peneliti dengan siswa-1 diatas diperoleh sebagai berikut:

a. Pada dasarmya siswa tersebut menunjukkan respon yang positif terhadap penggunaan KOBESI dalam Matematika GASING. Karena penggunaan KOBESI dalam proses pembelajaran membuat siswa belajar dengan lebih menyenangkan dan mudah untuk diingat.

b. Siswa lebih mudah memahami materi perkalian dengan menggunakan KOBESI dari pada cara belajar yang biasa. Karena dengan menggunakan KOBESI, materi perkalian yang sulit dipahami dan abstrak bagi siswa kelas III SD Curug Sangereng akan lebih mudah dimengerti.

Berdasarkan hasil wawancara dengan keempat siswa yang mewakili semua siswa kelas III SD Curug Sangereng pada umumnya siswa menyukai proses pembelajaran materi matematika dengan menggunakan KOBESI. Siswa memberikan tanggapan yang baik saat peneliti melakukan wawancara. Proses pembelajaran dengan menggunakan KOBESI dalam Matematika GASING dapat membuat proses pembelajaran menjadi lebih menyenangkan, mengasyikkan, dan dapat membantu siswa lebih mudah dalam memahami materi perkalian. Temuan tersebut menggambarkan bahwa media KOBESI dalam Matematika GASING dapat memberikan pengaruh positif didalam pembelajaran.

\section{KESIMPULAN}

Berdasarkan hasil dan pembahasan data diatas dapat disimpulkan bahwa terdapat perbedaan peningkatan yang sangat signifikan antara kemampuan pemahaman matematis siswa yang mendapat pembelajaran dengan menggunakan KOBESI dalam Matematika GASING dengan yang mendapat pembelajaran secara konvensional dengan ceramah. Peningkatan pemahaman matematis dikarenakan oleh perlakuan yang diberikan dimana pada kelas eksperimen peningkatannya sangat signifikan atau lebih baik dibandingkan dengan kelas kontrol sehingga dapat disimpulkan bahwa penggunaan KOBESI dalam Matematika GASING dapat meningkatkan pemahaman matematis siswa. 
Penggunaan KOBESI dalam Matematika GASING tidak hanya dapat meningkatkan kemampuan pemahaman matematis siswa tetapi juga dapat membuat proses pembelajaran menjadi lebih menyenangkan, mengasyikkan, dan dapat membantu siswa dalam memahami materi perkalian. Hal ini dilihat dari hasil wawancara yang dilakukan oleh peneliti. Dari hasil wawancara tersebut maka dapat disimpulkan bahwa respon siswa bersifat positif terhadap penggunaan KOBESI dalam Matematika GASING sehingga pada akhirnya dapat memberikan pengaruh positif pula di dalam pembelajaran.

\section{DAFTAR PUSTAKA}

Bani, A. (2011). Meningkatkan Kemampuan Pemahaman dan Penalaran Matematik Siswa Sekolah Menengah Pertama Melalui Pembelajaran Penemuan Terbimbing, SPS UPI, Bandung. UPI: Bandung.

Mediawati, E. (2011). Pembelajaran akuntansi keuangan melalui media komik untuk meningkatkan prestasi mahasiswa. Jurnal penelitian pendidikan, 12(1), 68-76.

National Council of Teachers of Mathematics. (2000). Principles and Standards for School Mathematics. America: Library of Congress Cataloguig in Publication Data.

Novianda, R., \& Sudaryati, S. (2015). Mengembangkan Pemahaman Matematika Siswa Terhadap Materi Sistem Persamaan Linear Dua Variabel (Spldv) dengan Pendidikan Matematika Realistik Indonesia (Pmri) Di Smp Negeri 1 Tambun Selatan. Jurnal Matematika Aplikasi dan Pembelajaran, 13(1).

Nurmasari, L. (2011). Peningkatan Kemampuan Menghitung Perkalian Melalui Metode Jarimatika Pada Siswa Kelas II SD Negeri 3 Pringanom Sragen Tabun Pelajaran 2010/2011 (Doctoral dissertation, Universitas Sebelas Maret).

Partanto, Plus A. M. Dahlan AL-Bary, 1994. Kamus Ilmiah Populer, Surabaya : Arkolo

Surya, Yohannes. (2013). Petunjuk Guru: Dasar-dasar Pintar Berbitung GASING. Tangerang: PT Kandel.

Siregar, J.H dkk. 2014. Learning the Critical Points For Addition in Matematika GASING, Journal on Mathematics Education, 5(2)pp. 160-169, Palembang

Sumaryati, E. (2013). Pendekatan Induktif-Deduktif Disertai Strategi Think-Pair-Square-Share Untuk Meningkatkan Kemampuan Pemahaman dan Berpikir Kritis serta Disposisi Matematis Siswa SMA. Jurnal Infinity, 2(1), 26-42.

Sukayati. (2003). Media Pembelajaran Matematika Sekolah Dasar.( Makalah Pelatihan Supervisi untuk Sekolah Dasar, tanggal 19 Juni s.d 12 Juli 2003, di PPPG Matematika Yogyakarta).

Sriyani, N., \& Sabri, T. (2014). Peningkatan Aktivitas Peserta Didik Dalam Pembelajaran Ilmu Pengetahuan Alam Menggunakan Media Realia Di Sd.Jurnal Pendidikan dan Pembelajaran, 3(12).

West, L., \& Bellevue, N. E. (2011). An Introduction to Various Multiplication Strategies. 